\title{
Notes
}

\section{Reestablishing the Federal Judge's Role in Sentencing}

\author{
Steve Y. Koh
}

A remarkably bipartisan effort to curb perceived sentencing disparities led to the enactment of the Sentencing Reform Act of 1984 (SRA). ${ }^{1}$ The Act established the United States Sentencing Commission (Commission) whose mandate, to promulgate guidelines to achieve "certainty and fairness" in the sentencing process for federal offenses, ${ }^{2}$ resulted in the Federal Sentencing Guidelines (Guidelines) in 1987.3 In the ensuing years, the Guidelines have met sharp criticism throughout the legal community ${ }^{4}$ and virtually no praise.

1. Pub. L. No. $98-473$, ch. 2,98 Stat. 1987 (1984) (codified at 18 U.S.C. $\S \S 3551-3673$ (1988); 28 U.S.C. $\S \S 991-998$ (1988)). The original sentencing legislation was cosponsored by, among others, Democratic Senators Kennedy, Biden, and DeConcini and Republican Senators Thurmond, Laxalt, and Hatch and was eventually enacted by a Senate vote of 91-1 and a House vote of 316-91. See S. REP. No. 225, 98th Cong., 2d Sess. (1984), reprinted in 1984 U.S.C.C.A.N. 3182-717.

2. 28 U.S.C. $\S 991$ (1988).

3. U.S. SENTENCING CO:MM'N, GUIDELINES MANUAL (1992) [hereinafter U.S.S.G.]. The Commission researched over one hundred thousand cases and held public hearings on a proposed draft before submitting the Guidelines to Congress in 1987. See Charles J. Ogletree, The Death of Discretion? Reflections on the Federal Sentencing Guidelines, 101 HARV. L. REV. 1938, 1948 (1988). Only Commissioner Paul Robinson dissented from the adoption of the Guidelines. See Sentencing Guidelines: Hearings Before the Subcomm. on Criminal Justice of the House Comm. on the Judiciary, 100th Cong., 1st Sess. 747 (1987) [hereinafter House Hearings] (testimony of Commissioner Robinson).

4. See, e.g., Sentencing Commission Guidelines: Hearing Before the Senate Comm. on the Judiciary, 100th Cong., 1st Sess. 472-509 (1987) [hereinafter Senate Hearings] (preliminary report of Ad Hoc Sentencing Study Group); FEDERAL COURTS STUDY COMM., REPORT OF THE FEDERAL COURTS STUDY COMMTTEE 133-44 (1990) [hereinafter FCSC REPORT]; The Sentencing Commission and Its Critics, 2 FED. SENTENCING REP. 206-51 (1990). One district court judge, J. Lawrence Irving, even resigned in protest of the Guidelines. Criticizing Sentencing Rules, U.S. Judge Resigns, N.Y. TIMES, Sept. 30, 1990, at A22. 
The centerpiece of the Guidelines is a 258-box grid. 5 The horizontal axis "criminal history category" calculates severity on the basis of the offender's past conviction record. ${ }^{6}$ The vertical axis "offense level" reflects the base score for a specific offense, adjusted by limited offense and offender characteristics.? The box at which the axes cross determines the applicable sentencing range. ${ }^{8}$ A judge may "depart" from the narrow range if the case exhibits factors the Commission failed to consider adequately in formulating the Guidelines and the judge states reasons for the departure. ${ }^{9}$ Appellate review is available to both the defendant and the government when the judge departs from the range. ${ }^{10}$

The Guidelines matrix and its underlying concept of sentencing have been attacked on two grounds. The broadest criticism challenges the very foundation of the SRA by asserting that "disparity," the sentencing of like offenders differently, was neither pervasive nor unwarranted under the pre-Guidelines regime. ${ }^{11}$ This disagreement derives from a fundamental rift over the proper definition of disparity, ${ }^{12}$ reflecting the basic inability of the sentencing reform movement to identify the primary purpose of punishment. ${ }^{13}$ Proponents of individualized justice, who generally focus on rehabilitation, regard most sentencing variations as the proper recognition of differences among offenders, ${ }^{14}$ while supporters of a just deserts model define the same variations as unwarranted disparity. ${ }^{15}$

It is important to note that the debate over the Guidelines and sentencing reform bears little, if any, relation to political ideology, and therefore should not be distorted by the characterization of critics as "liberals" and supporters as "conservatives." Republicans and Democrats align themselves on both sides of the issue, as do those considered "tough on crime" and those seen as "soft on crime." See Judge Jose A. Cabranes, Remarks before the Federal Bar Association, Hartford, Conn. 11 (May 17, 1990) (transcript on file with author) [hereinafter Cabranes Remarks].

5. U.S.S.G., supra note 3 , ch. 5, pt. A.

6. Id. $\S 4 \mathrm{~A} 1.1$.

7. Id. chs. 2-3. For example, the base score for importing obscene matter is six and increases by four if the material portrays sadistic or masochistic conduct. $I d$. $\$ 2 \mathrm{G} 3.1$. The offense level may be reduced by two if the defendant accepts personal responsibility. Id. $\S 3 \mathrm{E} 1.1$.

8. Id. ch. $5, \mathrm{pt}$. A. For instance, the sentencing range for an offender with an offense level of 26 and a criminal history category of four would be 92 to 115 months. Id.

9. 18 U.S.C. $\S 3553(\mathrm{~b})$, (c) (1988).

10. Id. § $3742(\mathrm{~b}),(\mathrm{c})$.

11. Many argue that studies and simulations aimed at measuring disparity are methodologically flawed because they fail to account for all of the relevant variables a decisionmaker considers. See House Hearings, supra note 3, at 246-48 (testimony of Judge Robert Sweet, S.D.N.Y.); Martin L. Forst, Sentencing Disparity: An Overview of Research and Issues, in SENTENCING REFORM: EXPERIMENTS IN REDUCING DISPARITY 10-15 (Martin L. Forst ed., 1982); Elyce H. Zenoff, Sentencing: Disparity, in 4 ENCYCLOPEDIA OF CRIME AND JUSTICE 1449, 1451-53 (Sanford H. Kadish ed., 1983) [hereinafter ENCYCLOPEDIA OF CRMIE].

12. See JACK M. KRESS, PRESCRIPTION FoR JUSTICE: THE THEORY AND PRACTICE OF SENTENCING GUIDELINES 19-20 (1980); infra note 111 and accompanying text.

13. As the prevailing theories of punishment have shifted among deterrence, rehabilitation, retribution, and incapacitation, so have conceptions of sentencing disparity. See MARVIN E. FRANKEL, CRIMNAL SENTENCES: LAW WITHOUT ORDER 105-11 (1973); Ogletree, supra note 3, at 1940-42.

14. See, e.g., Regional Public Hearing Before the United States Sentencing Commission, Chicago, Ill. 20 (1986) [hereinafter Chicago Hearing] (testimony of Terence MacCarthy, Director, Federal Public Defender Program, Chicago, IIl.) ("[S]o Iong as we have dissimilar defendants, we are going to have or should have dissimilar sentences.").

15. See KRESS, supra note 12, at 20; ANDREW VON HIRSCH, DOING JUSTICE 45-55 (1976). 
A second fundamental objection to the Guidelines charges a failure to address the interactive nature of the sentencing process by inappropriately concentrating exclusively on judicial discretion. ${ }^{16}$ In other words, attempts at confining judicial discretion run the risk of reallocating decisionmaking power in unintended and counterproductive ways. ${ }^{17}$ Thus, under the Guidelines, the prosecution's plea bargaining discretion enables the prosecutor essentially to dictate sentencing. ${ }^{18}$ As a result, while the Guidelines may minimize disparity between sentences issued by different judges, a hidden disparity emerges between pleas bargained by different prosecutors. ${ }^{19}$

This Note offers a third criticism that attempts to trace the judge's contribution to sentencing under the previous system, the current Guidelines structure, and a proposed future sentencing regime. The Note suggests that the current administrative, mathematical matrix improperly fosters judicial abdication of the duty of responsible and conscientious sentencing. It argues that a better approach to addressing issues of discretion and sentencing philosophy and their relation to disparity is to construct a new process that recognizes the traditional role of judges in sentencing.

Part I reviews the former system of multiple discretionary powers and notes that sentencing variations were basically consistent with the concept of individualized justice. It finds, however, that the virtues of overlapping discretion were largely nullified because judges were unable effectively and consistently to reconcile the competing views of other parties to the sentencing process. Part II describes the Sentencing Commission's response, which was to reduce drastically the discretion of sentencing judges. In particular, this part discusses the Commission's inability to create a framework responsive to different forms of discretion and representative of a coherent theory of punishment. These shortcomings, the Note argues, lead to judges' alienation from the sentencing process. Part III then addresses current sentencing practice and discusses how prosecutorial manipulation of the Guidelines calls for the reassertion of judicial discretion. Finally, Part IV presents an alternative approach that acknowledges

16. Questions of discretion are also tied to issues of sentencing philosophy. Agreement regarding the criteria that decisionmakers may legitimately consider depends upon the existence of a coherent sentencing philosophy. See BRUCE C. FREDERICK ET AL., N.Y. STATE DIVISION OF CRIMINAL JUSTICE SERVICES: THE EFFECTS OF LIMTING DISCRETION IN SENTENCING 29 (1984).

17. See Albert W. Alschuler, Sentencing Reform and Prosectutorial Power: A Critique of Recent Proposals for "Fixed" and "Presumptive" Sentencing, 126 U. PA. L. REV. 550 (1976); Stephen J. Schulhofer, Due Process of Sentencing, 128 U. PA. L. REV. 733, 748-55 (1980). Some even argue that the sentencing reform movement's targeting of judicial discretion was completely misplaced. Cabranes Remarks, supra note 4 , at 21 ("The exercise of discretion by a federal judge at sentencing was not, in my view, ever a weakness of the federal courts system-it was one of its strengths.").

18. See infra text accompanying note 73 .

19. See Sara S. Beale, Sentencing Guidelines, in 1 FEDERAL COURTS STUDY COMM., WORKING PAPERS AND SUBCOMMITTEE REPORTS 7-8 (1990); Gerald W. Heaney, The Reality of Guidelines Sentencing: No End to Disparity, 28 AM. CRM. L. REv. 161, 190-95, 202-03 (1991); Stephen J. Schulhofer \& Mene H. Nagel, Negotiated Pleas Under the Federal Sentencing Guidelines: The First Fifteen Months, 27 AM. CRIM. L. REV. 231, 256-88 (1989). 
the primary contribution of the judge to just sentencing and combats unwarranted sentencing disparity. The proposal reinstates the discretion characteristic of the pre-Guidelines regime, but creates sentencing panels and employs appellate review to inform and delimit the exercise of that discretion.

\section{THE JUdGE's ROLE UNDER THE PRIOR SYSTEM}

\section{A. The Input of the Various Players to the Sentencing Process}

Under the pre-Guidelines system, criminal sentences were shaped and modified by the discretion exercised by prosecutors, defense attorneys, probation officers, parole commissioners, and sentencing judges. The prosecutor's power to affect sentences through the allocation of investigative resources and the initial decision to bring a charge in a given case had largely been accepted as necessary to the effective administration of the criminal justice system. ${ }^{20}$ Less widely accepted, yet nearly as widespread, was the practice of overcharging defendants and subsequently bargaining to a reduced charge ${ }^{21}$ in order to give the prosecutor increased leverage to induce guilty pleas. Not only could the prosecutor threaten to proceed to trial with a twenty- or fifty-count indictment, but the addition of charges usually allowed for the introduction of otherwise inadmissible evidence and permitted greater flexibility in the event new information was discovered. ${ }^{22}$

Depending upon the practice of a particular prosecutor or a particular district, the treatment of individual criminals or certain classes of criminals varied widely. ${ }^{23}$ Thus, a measure of disparity was injected into the process before the judge even began presiding over a case. However, due to the latitude that pre-Guidelines sentencing accorded judges, ${ }^{24}$ the prosecutor's charging decision only had the practical effect of delimiting the defendant's maximum exposure..$^{25}$ Even so, the prosecutor's limited discretionary power arguably served a legitimate purpose by introducing the law enforcement viewpoint into the sentencing process.

Of course, any plea bargain necessarily required the agreement of the defendant. However, a defense attorney's ability to bargain at arm's length was

20. See William T. Pizzi, Prosecutorial Discretion, Plea Bargaining and the Supreme Court's Opinion in Bordenkircher v. Hayes, 6 HASTINGS CONST. L.Q. 269, 270-75 (1978).

21. Most criminal statutes enable prosecutors to multiply the number of accusations against a defendant or to charge an offense at a level higher than the facts warrant. See Albert W. Alschuler, The Prosecutor's Role in Plea Bargaining, 36 U. CHI. L. REv. 50, 85-89 (1968).

22. Id. at $91-92$.

23. Prosecutors could choose to offer more attractive bargains to burglars than to drug dealers to effectuate either personal values or some conception of community standards. Alternatively, the availability of a bargain could depend simply upon whether the prosecutor was too busy to proceed to trial. See James Vorenberg, Decent Restraint of Prosecutorial Power, 94 HARV. L. REV. 1521, 1533-34 (1981).

24. See infra notes 29-34 and accompanying text.

25. See, e.g., Regional Public Hearing Before the United States Sentencing Commission, Denver, Colo. 41 (1986) [hereinafter Denver Hearing] (testimony of William Price, U.S. Attorney, W.D. Okla.). 
hindered by the statistical reality that defendants convicted after trial received longer sentences than those who pleaded guilty. ${ }^{26}$ Defense counsel nevertheless always endeavored to obtain a sentence lower than that served by other similar defendants. In other words, the defense counsel's role was to introduce disparity into the sentencing process. Although the balance of power clearly tipped in favor of the prosecution, the defense counsel's objective played an important role in promoting the defendant's interests.

One restraint on the plea bargaining efforts of defense and prosecution was the probation officer, who submitted a presentence investigation report (PSI) to the sentencing judge. ${ }^{27}$ The PSI included both the defense's and prosecution's versions of the crime, descriptions of uncharged crimes, the defendant's prior record, assessments of the impact suffered by victims, and personal data ranging from marital status to work history. ${ }^{28}$ Under a system of indeterminacy, the information provided by the PSI was essential to the imposition of an informed, individualized sentence.

When issuing a sentence, the judge could freely draw upon any information in the PSI as well as virtually any other evidence found to be instructive. ${ }^{29}$ Absent statutory minimum sentences, the judge could impose a sentence ranging from probation or a fine to the maximum statutory punishment. ${ }^{30}$ This wide discretion provided a check on bargaining tactics by circumscribing gains achieved by the defendant from plea bargaining. ${ }^{31}$ To accomplish this result, judges used "real offense" sentencing, basing the sentence on the characteristics of the offense and the actual behavior of the defendant, rather than on the bargained-for charge. ${ }^{32}$ The defendant did not necessarily know the rationale behind his sentence since explanations were not required of the judge..$^{33}$ More-

26. See Albert W. Alschuler, The Trial Judge's Role in Plea Bargaining (pt. 1), 76 CoLUM. L. REV. $1059,1082-87$ (1976).

27. FED. R. CRM. P. 32(c).

28. Georgetown Law Journal Eighteenth Annual Review of Criminal Procedure: United States Supreme Court and Courts of Appeals 1987-1988 (pt. 4), 77 GEO. L.J. 1099, 1108-09 (1989); Keith A. Findley \& Meredith J. Ross, Comment, Access, Accuracy and Fairness: The Federal Presentence Investigation Report Under Julian and the Sentencing Guidelines, 1989 WIS. L. REV. 837, 840-41.

29. United States v. Tucker, 404 U.S. 443,446 (1972) (judge "largely unlimited either as to the kind of information he may consider, or the source from which it may come").

30. A defendant convicted of bank robbery, for example, could receive probation or imprisonment for up to 20 years, and/or a fine of up to $\$ 5000$. 18 U.S.C. $\$ \S 2113(a), 3651$ (1988).

31. See, e.g., John C. Coffee, Jr. \& Michael Tonry, Hard Choices: Critical Trade-Offs in the Implementation of Sentencing Reform through Guidelines, in REFORM AND PUNSHMENT: ESSAYS ON CRMINAL SENTENCING 155 (Michael Tonry \& Franklin E. Zimring eds., 1983). Thus, the judge's discretion prevented the disparity engendered by the law enforcement process. See Andrew J. Kleinfeld \& Thomas Eisele, The Sentencing Guidelines: Two Views From the Bench, FED. PROBATION, Dec. 1991, at 16.

32. Coffee \& Tonry, supra note 31, at 157. But see Vorenberg, supra note 23, at $1528 \mathrm{n} .23$ (charge still influential because it "colors how the judge views the offense and offender and influences how vigorously the prosecutor will argue for a stiff sentence").

33. Courts have historically avoided explaining the bases behind sentences. See PIERCE O'DONNELL ET AL., TOWARD A JUST AND EFFECTIVE SENTENCING SYSTEM 58 (1977). Moreover, the fact that a statement of reasons subjected the judge to the possibility of reversal provided an incentive to remain silent. See Eric F. Edmunds, Jr., Note, Disparity and Discretion in Sentencing: A Proposal for Uniformity, 25 UCLA L. REV. 323, 325 n.9 (1977). 
over, appellate review of sentences was virtually nonexistent outside narrow exceptions for sentences imposed beyond or inconsistent with the governing statute or based on constitutionally impermissible factors. ${ }^{34}$

Finally, the United States Parole Commission provided a significant restraint upon the judge's sentencing discretion. Applying uniform standards, ${ }^{35}$ the Parole Commission determined release dates and hence had the ability to level disparate sentences. ${ }^{36}$

\section{B. Implications of the Pre-Guidelines Approach}

The sentencing process, as it existed prior to the Guidelines, is best described as an arrangement of overlapping discretion. The prosecutor, defense attorney, probation officer, judge, and parole commissioner each added an element of discretion, and thus, disparity. Theoretically, this approach comported well with notions of individualized justice. ${ }^{37}$ The various actors, each with a particular informed perspective, were presumably free to make judgments on mitigating and aggravating circumstances. In particular, the judge considered myriad intangible factors that legislatures had historically regarded themselves ill equipped to consider. ${ }^{38}$ The aggregate effect of this decisionmaking calculus was therefore to accommodate a variety of appropriate viewpoints without permitting any one perspective to dictate the offender's sentence. ${ }^{39}$ This often led to the creative use of intermediate sanctions (those short of incarceration) as judges tailored sentences to the individual offender. ${ }^{40}$

Had the prior system worked in this ideal manner, sentencing variations would have been more defensible. Unfortunately, two major obstacles emerged. First, absent adequate communication, each player had too many opportunities to second-guess the others and to adjust his or her behavior accordingly. For instance, a prosecutor who considered a three-year sentence appropriate might have charged a defendant with an offense permitting a five-year rather than a three-year maximum sentence because he or she speculated that the judge would not impose the highest possible sentence. ${ }^{41} \mathrm{~A}$ judge might have engaged

34. See FRANKEL, supra note 13 , at $75-77$; Edmunds, supra note 33 , at 332-34.

35. 28 C.F.R. § 2.20 (1991).

36. See House Hearings, supra note 3, at 835 (testimony of Professor Albert Alschuler, University of Chicago Law School).

37. See VON HIRSCH, supra note 15 , at 98 ("Wide discretion in sentencing has been sustained by the traditional assumptions about rehabilitation and predictive restraint.").

38. See Alschuler, supra note 17 , at 556-57.

39. See Michael H. Tonry, Sentencing: Allocation of Authority, in 4 ENCYCLOPEDIA OF CRIME, supra note 11, at 1432; Franklin E. Zimring, Making Punishment Fit the Crime, HASTINGS CENTER REP., Dec. 1976, at 13, 16 (suggesting "three discretions may be better than one" at checking prosecutorial power).

40. See Herbert J. Hoelter, Arguing for Intermediate Sanctions Under the Guidelines, 4 FED. SENTENCING REP. 39, 40 (1991).

41. See Tonry, supra note 39 , at 1436 . Alternatively, the prosecutor might have attempted to exercise more control over the ultimate sentence by making a recommendation. However, she might have tempered this sentence recommendation to conform to a range the judge would find acceptable. See Schulhofer, supra 
in similar conjecture by, on the one hand, attempting to glean the prosecutor's intent from the charge and, on the other hand, discounting for the probable adjustment of the Parole Commission. ${ }^{42}$

Second, among the decisionmakers considered here, judges exercised perhaps the least guided discretion. Prosecutors, defense attorneys, probation officers, and parole commissioners could rely on their specifically defined roles for direction in the sentencing process. Conversely, judges, accustomed to being rational, somewhat distant arbiters equipped with a framework of procedural rules, statutes, and common law precedents, now faced the emotional, gut-wrenching task of sentencing with little outside guidance. ${ }^{43}$ In addition, the legal education and training undertaken by judges typically ignored sentencing issues. ${ }^{44}$ As a result, "[o]ne judge may sentence in order to rehabilitate, another to deter the offender ... from committing a similar crime, a third to incapacitate, while a fourth may sentence simply to "punish." "45

The pre-Guidelines process encouraged the presentation of a variety of legitimate viewpoints. Unfortunately, although studies indicate that judges agreed on the basic issues to consider in sentencing, these studies also assert that disparate sentences nevertheless occurred, because judges lacked a framework for translating this agreement into consistent sentencing. ${ }^{46}$ Consequently, when the Commission attempted to fulfill its statutory mandate, it sought to redefine the judge's role in sentencing to provide better guidance.

\section{The Sentencing Commission's Guidelines}

The practical justification for sentencing commissions is that such bodies, composed of "people of stature, competence, devotion, and eloquence," 47 are better equipped than legislatures are to create a flexible, evolving, and comprehensive sentencing system. ${ }^{48}$ Theoretically, a commission could proceed in

note 17 , at 745. Also, the policy in some jurisdictions, or of some judges, was not to allow recommendations. See Denver Hearing, supra note 25, at 81 (testimony of Judge John Kane, D. Colo.).

42. These series of moves and countermoves at times rendered the final sentencing outcome almost completely unpredictable. See, e.g., KRESS, supra note 12, at 46-48; Schulhofer, supra note 17, at 747-48.

43. Sentencing statutes provided judges little help. See, e.g., 18 U.S.C. $\S 3651$ (1982) (judge may grant probation "when satisfied that the ends of justice and the best interest of the public as well as the defendant will be served thereby"). As a result, judges were forced to sentence out of ignorance or to pursue their own sentencing philosophies. KRESS, supra note 12, at 37; O'DONNELL ET AL., supra note 33, at 2-3.

44. See FRANKEL, supra note 13 , at 12-15.

45. Edward M. Kennedy, Foreword to O'DONNELl ET AL., supra note 33, at viii.

46. One such study contends that judges consistently apply a common normative lens to sentencing that considers the harm produced by the crime, the blameworthiness of the offender, and the seriousness of the case. Extensive interviews revealed that judges will generally rank a set of cases similarly and yet disagree as to the proper sentence in an individual case. STANTON WHEELER ET AL., SITTING IN JUDGMENT: THE SENTENCANG OF WHITE COLLAR CRIMINALS 166-67 (1988); see also Shari S. Diamond, Exploring Sources of Sentence Disparity, in THE TRIAL PROCESS 387, 405 (Bruce D. Sales ed., 1981) (judges concur on the factors to examine in sentencing but disagree over the weight to be assigned to each variable).

47. FRANKEL, supra note 13, at 119-20.

48. Marvin E Frankel \& Leonard Orland, Sentencing Commissions and Guidelines, 73 GEO. L.J. 225, 247 (1984). 
an informed and rational manner to adopt a unifying sentencing rationale, which would permit both understanding and elimination of unwarranted disparity. ${ }^{49}$ A commission could also presumably examine and respond to the discretionary decisionmaking of every relevant party in the sentencing process. The Commission, however, did not accomplish these goals; instead, judges, accustomed to a role as the central figure in sentencing and the legitimate bearer of ultimate discretionary power, have found themselves with greatly diminished control. The approach which emerged from the Commission's deliberations neither reflects a coherent sentencing philosophy, as Congress anticipated, nor retains the balanced discretion of the pre-Guidelines system.

\section{A. The Failure of the Commission to Enunciate Purposes of Sentencing}

As the sentencing reform movement began to pick up pace in the 1970's, it appeared that an overarching sentencing philosophy was within reach. A number of commentators swiftly rejected the previously influential rehabilitative model in favor of a "just deserts" approach. ${ }^{50}$ Although a consensus on the proper role of punishment was not yet evident, the drafters of the SRA took a step towards developing a sentencing philosophy by requiring that courts consider the purposes of sentencing:

(A) to reflect the seriousness of the offense, to promote respect for the law, and to provide just punishment for the offense;

(B) to afford adequate deterrence to criminal conduct;

(C) to protect the public from further crimes of the defendant; and

(D) to provide the defendant with needed educational or vocational training, medical care, or other correctional treatment in the most effective manner. ${ }^{51}$

The legislative history of the SRA indicates that Congress recognized the importance of articulating the purposes of sentencing, and more significantly, the need for those purposes to influence the severity of actual sentences..$^{52}$ The

49. See FREDERICK ET AL., supra note 16, at 30; A. Keith Bottomley, Sentencing Reform and the Structuring of Pre-Trial Discretion, in SENTENCING REFORM: GUIDANCE OR GUDELLINES? 139, 140 (Martin Wasik \& Ken Pease eds., 1987).

50. This shift in emphasis from the criminal to the crime was the result of both disillusionment with the ability of the penal system to reform criminals and a more powerful sentiment that individualized sentencing was unjust and unfair. See Alschuler, supra note 17, at 552; Forst, supra note 11, at 18-21 (advocates of "justice" model urge punishments commensurate with seriousness of offense and not varying with characteristics of individual offender).

51. 18 U.S.C. \& 3553(a)(2) (1988). But see Stanley A. Weigel, The Sentencing Reform Act of 1984: A Practical Appraisal, 36 UCLA L. REV. 83, 99 (1988) (section "simply enumerates the several, often conflicting, purposes of sentencing").

52. See S. REP. NO. 225, supra note 1 , at 39, reprinted in 1984 U.S.C.C.A.N. at 3222; id. at 77, reprinted in 1984 U.S.C.C.A.N. at 3260 ("The intent of subsection (a)(2) is . . . to require that the judge consider what impact, if any, each particular purpose should have in each case."); see also Jack B. Weinstein, A Trial Judge's First Impression of the Federal Sentencing Guidelines, 52 ALB. L. REV. 1, 14 
task of researching and further developing rationales for sentencing remains the Commission's responsibility. ${ }^{53}$

A consistent theme voiced throughout the Commission's public hearings held after enactment of the SRA was that preliminary drafts of the Guidelines had lost sight of the multiple purposes of sentencing. A number of speakers expressed concern that the Commission had elevated retribution, in the form of incarceration, above all other principles as the primary objective in sentencing, ${ }^{54}$ while plainly disregarding rehabilitation..$^{55}$ In sum, speakers criticized the structure of punishments under the Guidelines for failing to correspond to the sentencing philosophies enunciated in the legislation..$^{56}$ The intensity of disapproval was such that perhaps the most common recommendation called for the Commission to return to Congress and seek clarification of the statutory mandate. ${ }^{57}$

Despite the number and variety of suggestions offered, the Commission itself did little to create a system of guiding principles. Commissioners apparently did not even agree on the appropriate method of incorporating the sentencing philosophies into the Guidelines. For instance, Commissioners appeared to be at odds over whether the rehabilitation goal should be deemphasized in all sentences or considered on a case specific basis. ${ }^{58}$ In the end, the Commission chose to express no rationale whatsoever, and instead "sought to solve both the practical and philosophical problems of developing a coherent sentencing system by taking an empirical approach that used as a starting point data estimating pre-Guidelines sentencing practice." 59

In other words, the Guidelines did little to further the debate over the proper goals of punishment. Commissioner Stephen Breyer defended the use

(1987) (imprisonment is not always appropriate punishment).

53. 28 U.S.C. \& 994(g) (1988).

54. See, e.g., Regional Public Hearing Before the United States Sentencing Commission, New York, N.Y. 155 (1986) [hereinafter N.Y. Hearing] (testimony of Judge Jon Newman, 2d Cir.); Regional Public Hearing Before the United States Sentencing Commission, Atlanta, Ga. 133 (1986) [hereinafter Atlanta Hearing] (testimony of Jay Cooper, Esq.). But see Regional Public Hearing Before the United States Sentencing Commission, Washington D.C. 505-06 (1986) [hereinafter D.C. Hearing] (testimony of Jeffrey Troutt, Institute for Government and Politics).

55. See, e.g., D.C. Hearing, supra note 54, at 480-81 (testimony of Charles Sullivan, Citizens United for the Rehabilitation of Errants); Atlanta Hearing, supra note 54, at 222-23 (testimony of Marcia Shein, Director, National Legal Services).

56. See, e.g., Atlanta Hearing, supra note 54, at 201 (testimony of Lucien B. Campbell, Federal Public Defender, W.D. Tex.); id. at 65 (testimony of Judge Gilbert Merritt, 6th Cir.). But see id. at 6-9 (testimony of Robert Barr, U.S. Attorney, N.D. Ga).

57. See, e.g., Denver Hearing, supra note 25, at 211 (testimony of Chief Judge Clarence Brimmer, D. Wyo.); Chicago Hearing, supra note 14, at 118 (testimony of Judge Michael Mihm, C.D. Ill.); N.Y. Hearing, supra note 54, at 33-34 (testimony of Judge Jack Weinstein, S.D.N.Y.). But see Atlanta Hearing, supra note 54, at 121 (testimony of Carlos Juenke, Chief Probation Officer, S.D. Fla.).

58. Commissioner George MacKinnon expected rehabilitation to play a lesser role in sentencing since Congress had placed it "at the bottom." D.C. Hearing, supra note 54, at 236; see also Atlanta Hearing, supra note 54, at 211. Conversely, Commissioner Helen Corrothers believed the Guidelines embodied a multiobjective system in which "a single objective will stand out as being most significant in a given situation." "House Hearings, supra note 3, at 738-39 n.4.

59. U.S.S.G., supra note 3 , ch. 1, pt. A, intro. cmt. 3. 
of typical past practices as a reasoned compromise necessitated by the institutional constraints of a group guidelines writing process. ${ }^{60}$ Commissioner Paul Robinson offered a different explanation: "[E]ven the pivotal decision to follow mathematical averages of past sentences was never the subject of Commission debate or discussion," but was "the result of last minute, private arrangements." ${ }^{\prime \prime}$ Indeed, haste and stormy infighting characterized the Commission's deliberations. ${ }^{62}$ Moreover, many decisions reflected the Commissioners' fear of disturbing the bipartisan Congressional consensus to "get tough on crime," which had prompted enactment of the SRA. ${ }^{63}$

Regardless of the reason, the Commission's failure to enunciate a sentencing philosophy represents a major flaw in the Guidelines. A sentencing rationale would have enabled the Commission to construct Guidelines capable of fulfilling defined societal objectives. The reliance on mathematical averages instead leads to sentences that sometimes further no particular purpose whatsoever. ${ }^{64}$ Moreover, the judge is left without adequate guidance concerning when to individualize a sentence by moving towards one end or the other of a range or when to depart altogether. ${ }^{65}$ Most significantly, without a sentencing rationale, judges, attorneys, defendants, and the public come no closer to understanding the reasons why a particular sentence is given.

60. Stephen Breyer, The Federal Sentencing Guidelines and the Key Compromises Upon Which They Rest, 17 HOFSTRA L. REV. 1, 15-18 (1988).

61. House Hearings, supra note 3, at 760 (statement of Commissioner Robinson).

62. Disputes over research, office politics, and the efficacy of working part time have led observers to question the ability of the Commission to amend and improve the Guidelines and have also contributed to the resignations of Commissioners Paul Robinson and Michael Block. See, e.g., Ruth Marcus, "Disarray" at Sentencing Commission; GAO Study Questions Panel's Ability 10 Assess New Guidelines, WASH. POST, Mar. 8, 1990, at A25 (reporting results of General Accounting Office study); Topics of the Times: Sentencing Policy, Disabled, N.Y. TIME, Dec. 19, 1989, at A26; Paula Yost, Sentencing Panel Member Resigns Over Research; Block Charges Lack of Commitment by Commissioners to Base Decisions on Data, WASH. POST, Aug. 23, 1989, at A25; Paula Yost, Sentencing Panel's Quandary: Whether to Work Part-Time; Commissioners' Clamor Spawns Congressional Probe, WASH. POST, Aug. 22, 1989, at A17.

63. See Breyer, supra note 60 , at 23-24 (Guidelines "that would have . . . significantly reduced typical prison sentences might have jeopardized the Congressional consensus."); Paula Yost, The Long-Term Debate; Charges of Politics Dog Sentencing Panel, WASH. POST, July 4, 1989, at A21 (researchers at Commission report being pressured to produce data supporting longer prison sentences).

64. For instance, a decision to pursue rehabilitation and deterrence goals with a drug addict may lead to the use of incarceration, supervised release, hospital care, community treatment, and fines. However, applying a mathematical average of prison terms given to drug dealers may satisfy neither purpose in any given case. Prison may fail to rehabilitate and also may not consistently deter, depending on individual characteristics. House Hearings, supra note 3, at 761 (statement of Commissioner Robinson); see also Ogletree, supra note 3, at 1952-53 (Commission failed to address underlying purposes of criminal sanctions).

65. See Senate Hearings, supra note 4, at 482 (preliminary report of Ad Hoc Sentencing Study Group); House Hearings, supra note 3, at 345 (statement of Andrew von Hirsch, Professor, Rutgers University School of Criminal Justice). Disparity will persist as judges continue to pursue their individual punishment philosophies. See id. at 762-63 (statement of Commissioner Robinson). 


\section{B. The Commission's Exclusive Focus on Judicial Discretion}

Efforts to eliminate disparity in sentencing have traditionally targeted judicial discretion. ${ }^{66}$ In this respect, the SRA was no different. ${ }^{67}$ To some extent the statute did address the other stages in the sentencing process by eliminating parole and by requiring the Sentencing Commission to develop policy statements regarding plea bargaining. ${ }^{68}$ The Commission's Guidelines, however, did not expand greatly on these congressional efforts.

The Commission certainly recognized that plea bargaining could undermine the Guidelines by permitting the prosecution and defense to agree privately to the particular facts and charges to which the defendant would plead. ${ }^{69}$ Under the Guidelines, this bargaining could effectively determine the sentence to be served. Nevertheless, the Commission opted to make no major effort to structure, control, or take account of plea bargaining and resolved instead to "study plea agreement practice under the guidelines and ultimately develop standards for judges." 70 The result was to limit drastically the Guidelines' ability to achieve fairness in the sentencing process.

Effective reform requires the development of reasoned sentencing principles to guide and inform judges in the exercise of their discretion. Congress, in enacting the SRA, envisaged the vehicle for such reforms to be a sentencing commission, endowed with the time, money, and expertise to craft a structure that would represent a coherent approach to punishment and that would adapt to the realistic interplay of discretion in the sentencing process. Neither purpose was accomplished. Consequently, the next part argues, the imperfect discretion of the pre-Guidelines approach has been replaced by an equally disturbing form of imperfect discretion that perpetuates unwarranted disparity.

\section{THE JUDGE'S ROLE UNDER THE GUIDELINES}

\section{A. The Prosecutor's Exercise of Discretion and De Facto Sentencing Power}

Under the Guidelines, as under the previous system, the prosecution and defense can manipulate charges in order to limit the defendant's sentence

66. See Coffee \& Tonry, supra note 31 , at 159; Zenoff, supra note 11, at 1450.

67. See S. REP. No. 225, supra note 1, at 792 (minority views of Senator Mathias) ("Underlying [the SRA] is a profound mistrust of the Federal Bench.").

68. 28 U.S.C. \& 994(a)(2)(E) (1988); see also S. REP. No. 225, supra note 1, at 167, reprinted in 1984 U.S.C.C.A.N. at 3350 .

69. See, e.g., Denver Hearing, supra note 25, at 247 (testimony of Michael Katz, Federal Public Defender, Denver, Colo.) ("We will find a way to distort what happened [and] [f]ind some offense that will fit in the result the prosecutor and defense lawyer desire. . . "); D.C. Hearing, supra note 54, at 101 (testimony of Henry Hudson, U.S. Attorney, E.D. Va); Schulhofer, supra note 17, at 748-57.

70. U.S.S.G., supra note 3, ch. 6, pt. B, intro. cmt.; see also Breyer, supra note 60, at 29-31; William W. Wilkins, Jr., Plea Negotiations, Acceptance of Responsibility, Role of the Offender, and Departures: Policy Decisions in the Promulgation of the Federal Sentencing Guidelines, 23 WAKE FOREST L. REV. 181, 185-90 (1988). 
exposure. Unlike the previous system, however, the plea bargain reached under the Guidelines will dictate the sentence within a very narrow range. Also, because the Guidelines heighten the importance of certain facts in a case, ${ }^{71}$ the ability of counsel to bargain over these facts creates opportunities for disparity. By bargaining over ambiguous or contested facts, the parties can recharacterize the offense and significantly reduce the defendant's sentence. Moreover, the prosecutor's power to influence the ultimate sentence is enhanced by a provision permitting downward departures based upon the offender's substantial assistance to law enforcement officials in investigating and prosecuting others. ${ }^{72}$ Because the departure can only be provided upon motion of the government, the question of whether assistance is "substantial" is left entirely to the discretion of the prosecutor. ${ }^{73}$

There is every indication that manipulation of the Guidelines occurs through charge and fact bargaining. The overwhelming majority of judges perceive that plea agreements frequently dismiss provable charges and that the parties often negotiate facts relevant to the Guidelines. ${ }^{74}$ Although the level of manipulation is impossible to pinpoint, studies indicate that it transpires in every district in at least a significant minority of cases. ${ }^{75}$ In the area of departures for substantial assistance, prosecutors sometimes make motions on behalf of defendants regardless of the quality of their assistance in order to induce guilty pleas, benefit defendants they find sympathetic, or mitigate sentences they consider too harsh. ${ }^{76}$

Without the overlapping discretion characteristic of the previous process, the prosecutor enjoys largely unchecked and unrestrained powers. Whatever counteracting effect the defense attorney once had in plea bargaining remains

71. With any system of guidelines, the procedures for developing facts are crucial since the sentence will represent many implicit findings of facts that do not comprise elements of the offense charged. See Peter B. Pope, Note, How Unreliable Factfinding Can Undermine Sentencing Guidelines, 95 YALE L.J. 1258 (1986). The Guidelines require increases or decreases in a sentence based upon certain factual offense characteristics. See, e.g., U.S.S.G., supra note 3, § 2A2.2(b)(2) (brandishing "dangerous weapon" during aggravated assault raises defendant's base score by three levels).

72. 18 U.S.C. § 3553(e) (1988); U.S.S.G., supra note 3, § 5K1.1; see also Bennett L. Gershman, Prosecutorial Discretion Under Federal Sentencing Guidelines, N.Y. L.J., Apr. 20, 1990, at 1. It is not suggested here that prosecutors have any greater power in this area than previously, but only that such power remains unchecked by judicial discretion under the Guidelines.

73. See Kimberly S. Kelley, Substantial Assistance Under the Guidelines: How Smitherman Transfers Sentencing Discretion From Judges to Prosecutors, 76 IowA L. REV. 187 (1990); Melissa M. McGrath, Comment, Federal Sentencing Law: Prosecutorial Discretion in Determining Departures Based on Defendant's Cooperation Violates Due Process, 15 S. ILL. U. LJ. 321 (1991).

74. One survey found that $83 \%$ of judges believe charge bargaining occurs frequently, and $73 \%$ believe fact bargaining occurs at least sometimes. Albert W. Alschuler \& Stephen J. Schulhofer, Judicial Impressions of the Sentencing Guidelines, 2 FED. SENTENCING REP. 94, 95 (1989).

75. See Beale, supra note 19, at 14-15; Schulhofer \& Nagel, supra note 19, at 272-82; Marcia Chambers, The Old Days: When a Plea Was a Plea, NAT'L L.J., Nov. 6, 1989, at 13; see also Daniel J. Freed \& Marc Miller, Plea Bargained Sentences, Disparity and "Guideline Justice," 3 FED. SENTENCING REP. 175, 175 (1991) ("Our hunch is that disparity among plea bargained cases is very high.").

76. See Schulhofer \& Nagel, supra note 19, at 268-71; Tracey Thompson, Applying a Formula to Justice; Sentencing Panels Limit Judges' Discretion, WASH. POST, June 12, 1989, at A1. 
limited. ${ }^{77}$ The probation officer's PSI also provides only an inconsistent and ineffective constraint on bargaining practices. Often, neither the defense nor the prosecution will cooperate with probation officers for fear that facts uncovered will upset their plea agreement. ${ }^{78}$ Even when the probation officer is able to present the court with an omitted fact, the prosecution and defense can rely on ambiguities of proof by stating that the evidence at trial would not support the probation officer's version of the facts. ${ }^{79}$

In addition, judges cannot readily review, much less check, the prosecutorial discretion exercised to attain plea bargains. The Commission responded to plea bargaining discretion by requiring that the agreements "adequately reflect the seriousness of the actual offense behavior" and that factual stipulations be accurate and honest. ${ }^{80}$ However, the efficacy of these requirements rests heavily on the ability of the judge to know or learn of relevant facts. ${ }^{81}$ Unless a judge aggressively dissects plea agreements, the limited discretionary authority granted judges under the Guidelines may be insufficient to counteract prosecutorial maneuvers. ${ }^{82}$

Similarly, the Guidelines adopt a "modified real offense sentencing" approach, which basically requires the court to sentence on the basis of "acts or omissions" for which the defendant is held responsible in addition to the offense for which the defendant is convicted ${ }^{83}$ This procedure seeks to limit the effectiveness of plea bargaining in determining the ultimate sentence by

77. See supra text accompanying note 26.

78. See Marcia Chambers, Probation Officers Sit in Judgment, NAT'L L.J., Apr. 16, 1990, at 13 (defense attomeys sometimes advise clients not to cooperate with probation officers, and some prosecutors maintain separate, edited case files for probation officer). Without sufficient resources, the probation officer must rely on the prosecutor's version of the facts. See Post-Mistretta Forum: How Can Guideline Sentencing Be Improved?, 1 FED. SENTENCNG REP. 357, 375 (1989) (statement of Judge Gerald W. Heaney, 8th Cir.). Moreover, variation in the effort probation officers exert to discover the facts in different cases, and in the degree of success they achieve, provides an enormous source of disparity among offenders' sentences. See United States v. Harrington, 947 F.2d 956, 966 (D.C. Cir. 1991) (Edwards, J., concurring); Kleinfeld \& Eisele, supra note 31, at 15-16; Heaney, supra note 19, at 201-02.

79. See Schulhofer \& Nagel, supra note 19 , at 276-78.

80. U.S.S.G., supra note $3, \S \S 6 \mathrm{~B} 1.2(\mathrm{a}), 1.4(\mathrm{a})$ (2). Beyond these provisions, the Guidelines approach to pleas essentially tracks existing procedural rules. See FED. R. CRR. P. 11; U.S.S.G., supra note 3, ch. $1, \mathrm{pt} . \mathrm{A}$, intro. 4(c).

81. See Beale, supra note 19, at 15; William W. Wilkins, Jr. \& John R. Steer, Relevant Conduct: The Cornerstone of the Federal Sentencing Guidelines, 41 S.C. L. REv. 495,500 (1990).

82. See, e.g., United States v. Bethancurt, 692 F. Supp. 1427, 1435-37 (D.D.C. 1988). An institutional tendency against challenging plea agreements may exist because judges are concerned with stalling the flow of cases through their courts. See Robert P. Schuwerk, Illinois' Experience With Determinate Sentencing: A Critical Reappraisal (pt. 1), 33 DEPAUL L. REV. 631, 643 n.62 (1984). The efforts of prosecutors to prevent prosecutorial evasion of the Guidelines have not been especially vigorous. U.S. DEP'T OF JUSTICE, PROSECUTOR'S HANDBOOK ON SENTENCING GUIDELINES AND OTHER PROVISIONS OF THE SENTENCING REFORM ACT OF 1984, at 45-48 (1987); Richard Thornburgh, U.S. Dep't of Justice March 13, 1989 Plea Policy for Federal Prosecutors, reprinted in 1 FED. SENTENCING REP. 421 (1989). Whatever restrictions exist are not taken very seriously by assistant U.S. attorneys. See Tony Garoppolo, Confusion and Distortion in the Federal Sentencing Process, 27 CRM. L. BULL. 3, 15 (1991); Schulhofer \& Nagel, supra note 19, at 265 (some prosecutors appeared to consider the Justice Department manual "a form of naive and unwanted outside interference; it was regarded with a feeling just short of contempt").

83. U.S.S.G., supra note $3, \S 1 \mathrm{~B} 1.3$. 
permitting the court to look beyond the charge to the offender's real offense behavior. ${ }^{84}$ Again, without accurate factual development this provision cannot produce the desired effect. ${ }^{85}$

Finally, regardless of the decisions of prosecutors, defense attorneys, probation officers, and judges, the Parole Commission under the previous regime could level disparate sentences. The SRA eliminated this last potential check.

The prosecutor thus, in effect, retains discretion under the Guidelines to generate disparate sentences. ${ }^{86}$ Indeed, as many courts have recognized, the Guidelines have essentially transferred sentencing discretion from judges to prosecutors. ${ }^{87}$ That the prosecutor exercises this discretion should surprise no one. Given the nature of the criminal justice system, even ethical prosecutors, undeniably pressured to obtain convictions in every case, do not feel compelled to resolve abstract issues of disparity. ${ }^{88} \mathrm{~A}$ prosecutor's bargaining position is determined not by a perception of what sentences "similar" defendants do or should receive, but by caseload pressures, weaknesses in a particular case, and the need to secure timely guilty pleas. ${ }^{89}$ Finally, many prosecutors evade the

84. See Wilkins \& Steer, supra note 81 , at 499.

85. See Schulhofer \& Nagel, supra note 19, at 247 ("II]f the prosecutor opts not to provide evidence to support a specific offense characteristic, the judge's hands are tied, despite the 'real offense' principle that governs Guideline determinations."). United States v. Easterling vividly illustrates the potential for disparity. 921 F.2d 1073 (10th Cir. 1990), cert. denied, 111 S. Ct. 2066 (1991). If the district court had accepted the plea agreement and PSI, which reported a conspiracy to distribute 0.8 grams of methaamphetamine, the Guidelines' sentencing range would have been 6 to 12 months. Id. at 1075 . Based on information the court had obtained from the Probation Office, however, an amended PSI was ordered, which

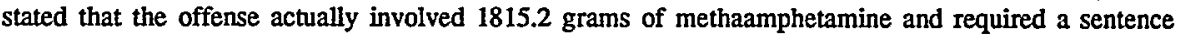
between 78 and 97 months. $I d$. at $1075 \mathrm{n} .3,1076$.

86. Judge Harry Edwards summarized the problem:

We ... have come to understand that the Guidelines do not, by any stretch of the imagination, ensure uniformity in sentencing. Assistant U.S. Attorneys ... have been heard to say, with open candor, that there are many "games to be played," both in charging defendants and in plea bargaining, to circumvent the Guidelines. Because of this reality, sentences under the Guidelines often bear no relationship to what the Sentencing Commission may have envisioned as appropriate in any given case.

United States v. Harrington, 947 F.2d 956, 964 (D.C. Cir. 1991) (Edwards, J., concurring).

87. See United States v. Stanley, 928 F.2d 575, 583 (2d Cir.), cert. denied, 112 S. Ct. 141 (1991); United States v. Kikumura, 918 F.2d 1084, 1119 (3rd Cir. 1990) (Rosenn, J., concurring); United States v. Chotas, 913 F.2d 897, 905 (11th Cir. 1990) (Clark, J., specially concurring in part and dissenting in part), cert. denied, 111 S. Ct. 1421 (1991); United States v. Correa-Vargas, 860 F.2d 35, 39 (2d Cir. 1988); United States v. Smith, 727 F. Supp. 1023, 1029 (W.D. Va. 1990).

88. See Randolph N. Jonakait, The Ethical Prosecutor's Misconduct, 23 CRM. L. BULL. 550 (1987).

89. See Schulhofer \& Nagel, supra note 19, at 283. For example, a prosecutor may threaten during negotiations to reindict a defendant on more serious charges if the defendant refuses to plead guilty. The Supreme Court has held this not to be a violation of due process. Bordenkircher v. Hayes, 434 U.S. 357 (1978); see also United States v. Goodwin, 457 U.S. 368 (1982) (pretrial reindictment on more serious charges following defendant's request for jury trial does not give rise to presumption of vindictiveness). In addition, in cases involving multiple defendants, the prosecutor may bargain aggressively and quickly with the defendants whose assistance is needed to "make" the case against the remaining defendants. The point here is not that these considerations are illegitimate but that they relate indirectly or even perversely to the goal of minimizing disparity. In other words, plea bargaining by its very nature creates disparities. 
Guidelines out of a concern that failure to induce adequate numbers of guilty pleas will sink an already overburdened federal criminal justice system. ${ }^{90}$

Whether any of these reasons applies in a particular case, the defendant, judge, and the public will never know. While prosecutors often grant sentencing concessions in an effort to fulfill their own sense of justice, ${ }^{91}$ they may also conceivably consider racial or other impermissible factors. One can only be sure that the existence of sentencing disparity will depend in part upon which prosecutor is assigned to the case. ${ }^{92}$

\section{B. The Judge's Unguided Exercise of Discretion}

Prosecutor-driven disparity is exacerbated by the fact that no coherent sentencing philosophy guides the judicial discretion that remains under the Guidelines. The Guidelines permit a district court to depart from the specified sentencing ranges when it finds an aggravating or mitigating circumstance of a kind, or to a degree, not adequately considered by the Commission in formulating the Guidelines. ${ }^{93}$ However, this is a tall order to fill: the Commission considered a number of potentially mitigating circumstances, such as age, education, mental condition, and family responsibilities, and deemed them "not ordinarily relevant" in making the departure determination. ${ }^{94}$ In reviewing departures, courts of appeals have strictly construed this language. ${ }^{95}$ Furthermore, the nonreviewability of a district court's failure to depart provides another incentive against departure. ${ }^{96}$

90. See Beale, supra note 19 , at 10.

91. See supra text accompanying note 76.

92. See United States v. Boshell, 728 F. Supp. 632, 638 (E.D. Wash. 1990) ("The critical first inquiry for any defense lawyer in assessing the seriousness of the case against his or her client is not the offense charged, but which AUSA is handling the matter."). Sometimes the discretion may not even be exercised by the prosecutor handling the case. In at least one district, decisions on whether to move for downward departure are made by a secret committee that determines which defendants will be permitted to cooperate with the government. See Marcia Chambers, Sentencing By Secret Committee?, NAT'L L.J., Jan. 22, 1990, at 13 (describing practice in District of Columbia).

93. 18 U.S.C. $\S 3553(b)$ (1988).

94. U.S.S.G., supra note 3, §§ 5H1.1-1.10.

95. Many decisions have reversed district court departures based on certain offender characteristics because the Guidelines already account for them. See, e.g., United States v. Pozzy 902 F.2d 133, 138-39 (1st Cir.) (pregnancy), cert. denied, 111 S. C. 333 (1990); United States v. Daiagi, 892 F.2d 31, 34 (4th Cir. 1990) (old age); United States v. Sutherland, 890 F.2d 1042, 1043 (8th Cir. 1989) (family ties and responsibilities); United States v. Palta, 880 F.2d 636, 639 (2d Cir. 1989) (attempt to conceal identity). But departures have also been upheld on the basis of the Commission's failure to consider certain factors. See, e.g., United States v. Lara, 905 F.2d 599, 602-03 (2d Cir. 1990) (susceptibility to homosexual attack); United States v. Ryan, 866 F.2d 604, 609-10 (3rd Cir. 1989) (quantity, purity, and packaging of drugs).

96. So long as the failure to depart is not based upon an erroneous interpretation of the law, a refusal to depart is not reviewable. See, e.g., United States v. Morales, 898 F.2d 99, 101 (9th Cir. 1990); United States v. Evidente, 894 F.2d 1000, $1003-04$ (8th Cir.), cert. denied, 110 S. Ct. 1956 (1990); United States v. Denardi, 892 F.2d 269, 272 (3d Cir. 1989); United States v. Tucker, 892 F.2d 8, 11 (1st Cir. 1989); United States v. Draper, 888 F.2d 1100, 1105 (6th Cir. 1989); United States v. Franz, 886 F.2d 973, 978 (7th Cir. 1989); United States v. Rojas, 868 F.2d 1409, 1410 (5th Cir. 1989). 
Nevertheless, judges do have the opportunity to depart. The point is not that judges are unable to individualize sentences by departing or by sentencing at either end of a range, but rather that in exercising this discretion, judges use different sentencing philosophies and thus arrive at disparate sentences. Those judges disposed to rigidity defer to the Guidelines' ranges, while those who prefer leniency search for loopholes. ${ }^{97}$ Even when two judges sentence two identically situated defendants within a particular range, the sentences may legally differ by as much as twenty-five percent..$^{98}$ Alternatively, judges who feel powerless to individualize sentences or are otherwise hostile to the Guidelines tolerate and even encourage evasion of the Guidelines. ${ }^{99}$

This failure of the Guidelines to develop a sentencing rationale contributes to what many judges feel is a painful choice between injustice to the defendant and infidelity to the Guidelines. ${ }^{100}$ As a result, what sentence a defendant receives can still depend largely upon which judge presides at sentencing-precisely the situation the Guidelines were designed to eliminate.

\section{The Consequences of the Guidelines Approach}

Disparity is alive and well under the Guidelines. First, many of the same criticisms leveled against judicial sentencing under the prior system also apply to the de facto sentencing by prosecutors under the Guidelines. It can be arbitrary and unpredictable, depending more on the inclinations of the particular prosecutor than on any rational or quantifiable process. In many ways, however, the current approach is worse than the previous one. Prosecutors are no doubt subject to a wider range of pressures, from adversarial to professional to political, than are judges. ${ }^{101}$ Furthermore, if discretion is to be exercised in sentencing, it seems unwise to vest it in the typically less experienced, less knowledgeable prosecutor. ${ }^{102}$ Beyond altering the power structure of the sentencing process, the Guidelines have also altered its nature by driving discretion

97. See United States v. Harrington, 947 F.2d 956, 965 (D.C. Cir. 1991) (Edwards, J., concurring) ("[W] hether the [Guidelines] actually get bent may depend upon the luck of the draw in judicial assignment: if the trial judge is willing to look the other way, the facts can be manipulated and the Guidelines ignored ...."); Marcia Chambers, A Sentencing Plan That's Incomplete, NAT'L L.J., Oct. 26, 1987, at 13; Katherine Oberlies, Reviewing the Sentencing Commission's 1989 Annual Report, 3 FED. SENTENCING REP. 152, 153 (1990). At least where judges opt for the departure "loophole," appellate review may provide some guidance. However, where the court acquiesces to Guidelines manipulation or sentences at one end of a range, the review safeguard is unavailable.

98. 28 U.S.C. $\$ 994(b)$ (1988). In addition, the mere fact that a sentence is within a Guidelines range says nothing about the decisions a judge may have made in establishing that range.

99. See Senate Hearings, supra note 4, at 261 (statement of Chief Judge G. Thomas Eisele, E.D. Ark); Schulhofer \& Nagel, supra note 19 , at 261 . In this way, judges may use prosecutorial discretion toward their sense of a just sentence without departing from the Guidelines.

100. See Thomas W. Hillier, II, Congressional Oversight, 2 FED. SENTENCING REP. 224, 226 (1990).

101. See supra notes $88-90$ and accompanying text.

102. See United States v. Boshell, 728 F. Supp. 632, 637 (E.D. Wash. 1990) (comparing selection procedures of judges and U.S. attorneys); SANDRA SHANE-DUBOW ET AL., SENTENCING REFORM IN THE UNITED STATES: HISTORY, CONTENT AND EFFECT 11 (1985); Alschuler, supra note 17, at 564. 
underground so that issues of disparity reach resolution through negotiations between prosecution and defense instead of before the court. ${ }^{103}$

Second, the imposition of disparate sentences by judges is more objectionable now than it was prior to enactment of the Guidelines. In the past, judges invested substantial energy and emotion into fashioning appropriately individualized sentences. Today, the arithmetic and technical nature ${ }^{104}$ of the Guidelines deprives judges of the sense of personal responsibility for principled sentences. According to one judge, "[t] distances the court from the offender, as well as from the reasons for punishment." 105 While some judges still fight to introduce their sense of fairness, others withdraw from the process out of frustration. ${ }^{106}$ Moreover, the complexities and ambiguities of the Guidelines make it common for judges to differ honestly as to the applicability of a particular provision. ${ }^{107}$ Whatever the Tenn.).

103. See Atlanta Hearing, supra note 54, at 24-25 (testimony of Joe Brown, U.S. Attorney, M.D.

104. An example is the spurious objectivity of varying the length of a robber's imprisonment by the number of dollars stolen. U.S.S.G., supra note 3, \$ 2B3.1(b)(6). As one judge objected: "The point is, the person who came in to rob the bank intended to get everything that was in that cash drawer regardless of the amount, and the seriousness of the event [makes] very little difference." D.C. Hearing, supra note 54, at 164 (testimony of Judge William O'Kelley, N.D. Ga.).

Even more problematic is the requirement that an LSD dealer's sentence be calculated on the basis of the "mixture or substance containing a detectable amount of" LSD. 21 U.S.C. $\S 841$ (b)(1)(B)(v) (1988); U.S.S.G., supra note 3, § 2D1.1(c) n.*. The Supreme Court has upheld this provision, mandating that the weight of both the LSD and the medium in which it was carried be used to determine the dealer's sentence. Chapman v. United States, 111 S. Ct. 1919 (1991). The absurd result is that, under the Guidelines, a first offender selling 100 doses of LSD would be sentenced to 188 to 235 months for using sugarcubes, 63 to 78 months for using blotter paper, 27 to 33 months for using gelatin capsules, and only 10 to 16 months if the drug were sold in pure form. Id. at 1924 n.2. As Judge Posner noted in his dissent to the lower court opinion, this scheme bears no relation to the defendant's culpability and furthers no rational sentencing purpose. United States v. Marshall, 908 F.2d 1312, 1333 (7th Cir. 1990) (Posner, J., dissenting) ("A person who sells LSD on blotter paper is not a worse criminal than one who sells the same number of doses in gelatin cubes, but he is subject to heavier punishment. . . . [E]ven the Justice Department cannot explain the why of the punishment scheme it is defending ...."). Moreover, the result is huge disparity among LSD dealers selling an equal number of doses, and huge disparity between LSD dealers and other drug dealers. Id. at 1335.

105. House Hearings, supra note 3, at 266 (testimony of Judge Robert W. Sweet, S.D.N.Y.).

106. See Albert W. Alschuler, Departures and Plea Agreements Under the Sentencing Guidelines, 117 F.R.D. 459, 469 (1987) ("Some judges . . . plan to go by the book, to play it safe, to stop thinking, and to stop caring."); Denver Hearing, supra note 25, at 84 (testimony of Judge John Kane, D. Colo.); see also United States v. Harrington, 947 F.2d 956, 967 (D.C. Cir. 1991) (Edwards, J., concurring) ("We continue to enforce the Guidelines as if, by magic, they have produced uniformity and fairness, when in fact we know it is not so."). Some frustrations relate to the burdens caused by the Guidelines. Id. ("[The courts of appeals], the district courts, the U.S. Attorney's Office and the defense bar are forced to press on-through contorted computations, lengthy sentencing hearings and endless appeals . . . .") (footnote omitted). Judges are reporting more meritless motions, cases, and objections as defendants fight the severity of the Guidelines. See Letter from Judge Judith N. Keep (S.D. Cal.), member of the Federal Courts Study Committee, to colleagues (Oct. 1, 1990) (on file with author) ("WW]e spin our wheels on criminal matters that are time consuming and meritless, and we are unable to devote an appropriate period of time to our civil cases.").

107. See Letter from Judge Myron H. Bright, 8th Cir., to Judge William W. Wilkins, U.S. Sentencing Commission Chairman (Oct. 31, 1990) (on file with author) (citing several cases in which subjective interpretation of Guidelines governed sentence imposed); see also United States v. O'Meara, 895 F.2d 1216, 1223 (8th Cir.) (Bright, J., dissenting) ("IT]he implementation of the present guideline system is highly dependent on the judgment calls of fallible human actors . . . "), cert. denied, 111 S. Ct. 352 (1990). 
cause, disparity is the result, demonstrating the failure of the Guidelines system to inform and advance an understanding of sentencing.

Perhaps worst of all, the public is being misled about the extent of disparity under the Guidelines. The Commission's 1989 Annual Report boasts that eighty-two percent of the sentences issued during that year were within the Guidelines range as established by the court. ${ }^{108}$ This rather simplistic compliance data ignores the types of prosecutorial and judicial decisionmaking discussed in this Note. ${ }^{109}$ Moreover, no empirical study can adequately measure the reduction in disparity because notions of disparity depend upon normative conceptions of the proper goals of sentencing. ${ }^{110}$ Thus, the conclusion that disparity has been reduced proves only that the Guidelines system has more consistently applied its own criteria, not that it is any "fairer" than the preGuidelines regime. ${ }^{111}$

Unfortunately, incremental improvements to the Guidelines will not solve the problem. ${ }^{112}$ The Guidelines are not performing adequately, and attractive alternatives, such as the one proposed in this Note, are available.

\section{A Judictally Managed Process of Checks and Balances}

Those who design a sentencing process must recognize that discretion is not an evil per se. Rather, discretion should be viewed as an inevitable compo-

108. Of the remaining cases, $5.8 \%$ departed downward upon substantial assistance motions, $8.7 \%$ departed downward for other reasons, and 3.5\% departed upward. U.S. SENTENCING COMM'N, 1989 ANNUAL REPORT 2. These rates have been cited as evidence that the Guidelines are a success. See Sentencing Guidelines Work, WASH. POST, July 26, 1989, at A24. Independent empirical studies have also purported to find a reduction in certain types of disparity under the Guidelines. See Theresa W. Karle \& Thomas Sager, Are the Federal Sentencing Guidelines Meeting Congressional Goals?: An Empirical and Case Law Analysis, 40 EMORY L.J. 393, 407 (1991).

109. See supra notes 74-79, 97-99 and accompanying text. In other words, if prosecutors manipulate the Guidelines through plea bargaining and judges acquiesce in this evasion, the Commission's "compliance rates" prove nothing: the real conduct of the defendants sentenced in a particular range will actually differ dramatically and hence reflect disparity. See Hearings Before the United States Sentencing Commission on Proposed Amendments (statement of Judges Vincent L. Broderick and Mark Wolf) (1991), reprinted in 3 FED. SENTENCING REP. 276, 281 (1991) [hereinafter Amendment Hearings]; Michael Tonry, Are the U.S. Sentencing Commission's Guidelines “Working Well”?, 2 FED. SENTENCING REP. 122, 123 (1989).

110. See supra text accompanying notes 11-15.

111. See Albert W. Alschuler, The Failure of Sentencing Guidelines: A Plea for Less Aggregation, 58 U. CHI. L. REv. 901, 916-17 (1991) ("'R]esearchers have concluded in effect, "Judges in our guidelines system have come closer to following the guidelines than judges did before the guidelines were invented.' "). As Professor Alschuler explains, while the Guidelines may treat all defendants who committed the same offense alike, it may not treat all defendants with similar culpability alike. Id. at 917. Consequently, empirical comparison of disparity between sentencing systems with different criteria is impossible. Id.

112. House Hearings, supra note 3, at 344-46 (statement of Andrew von Hirsch); see also Letter from Michael Katz, Federal Public Defender, D. Colo., to Commissioner Ilene Nagel, U.S. Sentencing Commission (Feb. 21, 1990), reprinted in 2 FED. SENTENCING REP. 229 (1990) (hostility of Commission to criticism will hinder improvements). Several participants in the Guidelines amendment process, mandated by 28 U.S.C. \& 994(0) (1988), complained that the Commission adhered to an internal agenda and ignored the input of others. See Fred W. Bennett, A Direct Participant's Perspective on the Guideline Amendment Process, 3 FED. SENTENCING REP. 148, 149 (1990); Avern Cohn \& Vincent L. Broderick, Correspondence Between District Judges, 4 FED. SENTENCING REP. 48, 49 (1991). 
nent of the criminal justice system that, when exercised properly, permits consideration of the myriad individual characteristics unaccounted for in a guidelines matrix. On the other hand, justifying a decision by mere reference to a decisionmaker's discretion can be a way of shirking an obligation to present a convincing rationale for the decision. ${ }^{113}$ Therefore, the goal of sentencing reform should not be to reduce the absolute amount of discretion available in the system, but to require that it be checked, balanced, and explained in a manner that promotes just sentencing. Finally, a successful sentencing process must have the support of the judges who administer it. ${ }^{114}$

\section{A. Sentencing Panels To Inform and Check Discretion}

\section{A Proposal}

To begin with, the current Guidelines should be scrapped and the Commission redirected toward establishing a recast guidelines framework based upon general rules of decision. Professor Albert Alschuler has offered one promising approach: authorize the Commission to draft a type of administrative precedent for "recurring paradigmatic cases." 115 The Commission, under Alschuler's proposal, would study these "normal" cases, such as that of a disadvantaged young man who engages in small-scale drug dealing because of the prospect of easy money, and identify an appropriate sentence based upon the sentencing purpose(s) considered most important in that type of case. ${ }^{116}$ This sentence would act something like a precedent, which district courts could either follow or distinguish. ${ }^{117}$ If this approach, or some variant thereof, were adopted, the guidelines would serve not to constrain judges rigidly but to provide them with a reasoned starting point for further deliberation. ${ }^{118}$

These precedential guidelines would assist each judge's individual decisionmaking calculus. In order to enhance communication among judges, sentencing could be performed by rotating three-judge panels, sitting perhaps weekly or monthly to sentence cases they had accumulated. Prior to sentencing, the judges would have the benefit of the probation officer's PSI, and at sentencing, the judges could note the defendant's demeanor evidence and testimony. During

113. See George P. Fletcher, Some Unwise Reflections About Discretion, 47 LAW \& CONTEMP. PROBS., Autumn 1984, at 269, 284.

114. See S. REP. NO. 225, supra note 1, at 792 (minority views of Senator Mathias).

115. Alschuler, supra note 111 , at $939-41$.

116. Id. at 941-44. Besides suggesting sentences, the Commission could also formulate basic rules and standards regarding the use of intermediate sanctions. See id. at 945.

117. Id. at 945 . In many respects, the Alschuler proposal suggests essentially what early sentencing reformers sought from a sentencing commission. See FRANKEL, supra note 13, at 118-23.

118. These guidelines would also play an important role in developing a principled common law of sentencing by providing a benchmark against which a judge could compare her sentences and, perhaps, her sentencing philosophy as well. Moreover, appellate courts would have a standard that would aid the evaluation of sentences. See infra note 157 and accompanying text. 
a recess, the judges would confer, and a majority decision would determine the sentence. All sentences imposed would require a statement of reasons together with any dissenting opinion. The sentencing panel would be obligated, in its sentencing statement, either to adhere to the Commission's precedential guidelines or to distinguish the case. In either scenario, our understanding of sentencing would be advanced by an instructive dialogue established among judges as well as between the Commission and the courts.

\section{Experience With Sentencing Councils}

Sentencing councils, established during the 1960's in federal district courts in Detroit, New York, and Chicago, resembled the proposed panels in many respects. ${ }^{19}$ Unlike the panels, however, these councils met informally, the recommendations of the other judges did not bind the sentencing judge, and no guidelines existed. ${ }^{120}$ Participating judges expressed great enthusiasm about the councils, reporting that the process had led to more principled and objective judicial attitudes, virtual unanimity on the factors most relevant to sentencing, increased use of sentencing options, and a heightened appreciation for the importance of sentencing purposes. ${ }^{121}$ The council meeting was an educational process that pooled knowledge and experience, served to acclimate new judges, and moderated the views of older colleagues. ${ }^{122}$

Despite the uniformly laudatory reviews of judges, however, a number of statistical studies concluded that councils did very little to diminish impermissible disparity. ${ }^{123}$ The studies found that the nonbinding nature of the council recommendations permitted judges to continue to pursue individual notions of justice and even polarized the views of some judges. ${ }^{124}$ The commentators argued that three judges could not determine the principles of sentencing any better than one judge could. ${ }^{125}$ The panels suggested in this Note respond to

119. See Richard F. Doyle, A Sentencing Council in Operation, FED. PROBATION, Sept. 1961, at 27; Charles T. Hosner, Group Pracedures in Sentencing: A Decade of Practice, FED. PROBATION, Dec. 1970, at 18 .

120. See Doyle, supra note 119; Hosner, supra note 119.

121. See Theodore Levin, Toward a More Enlightened Sentencing Procedure, 45 NEB. L. REV. 499, 505 (1966); Talbot Smith, The Sentencing Council and the Problem of Disproportionate Sentences, 11 PRAC. LAW. 12, 20-21 (1965); Joseph C. Zavatt, Sentencing Procedures in the United States District Court for the Eastern District of New York, 41 F.R.D. 469, 479-81 (1966). The last alleged benefit deserves special emphasis. As Judge Zavatt wrote, the councils caused judges to recognize "that the particular offense is not necessarily the critical factor in determining the appropriate sentence, if the sentence is to serve a truly valid and constructive function." $I d$. at 480 .

122. See Levin, supra note 121, at 508; Smith, supra note 121, at 20; Zavatt, supra note 121, at 480.

123. FEDERAL Judicial CENTER, THE EFFECTS OF SENTENCING COUNCILS ON SENTENCING DISPARTTY 14-15 (1981); ChARLES D. PHILLIPS, SENTENCING COUNCILS IN THE FEDERAL COURTS 99-100 (1980); Shari S. Diamond \& Hans Zeisel, Sentencing Councils: A Study of Sentence Disparity and Its Reduction, 43 U. CHI. L. REV. 109, 146-47 (1975). But see Michael H. Tonry, Sentencing Councils, in 4 ENCYCLOPEDIA OF CRME, supra note 11 , at 1483,1484 (challenging credibility of these studies).

124. O'DONNELL ET AL., supra note 33, at 18; PHILIPS, supra note 123, at 94-95.

125. See ANTHoNy Partridge \& William B. Eldridge, Federal Judicial Center, The SeCond CIRCUIT SENTENCING StudY: A REPORT TO THE JUdGES OF THE SECOND CirCuIT 33-34 (1974). 
both criticisms. First, since the panels require concurrence, a judge would necessarily respond to the other judges' views and adjust her own perspective accordingly. Second, because the panels would receive precedential guidelines, panels would be afforded the sentencing experience of a body of full-time sentencing experts.

\section{Advantages of Sentencing Panels}

Sentencing panels would play a central role in a new sentencing system. Perhaps the greatest appeal of panels lies in their procedural form, requiring judges to be both active and interactive. The panels would encourage the sharing of experiences and wisdom that occurred in sentencing councils, ${ }^{126}$ and the requirement of sentencing rulings would concretize the dialogue on sentencing. ${ }^{127}$ By informing this discussion with precedential guidelines, disparity resulting from differences in sentencing philosophy would be limited.

Moreover, panels could also limit disparity by checking discretion in two ways. First, basic to the SRA was the notion that only disparity that falls outside of some acceptable bounds should be eradicated. ${ }^{128}$ Mandating the concurrence of at least two judges would severely check the discretion of any one judge to sentence far outside the norm. Second, elimination of the Guidelines regime and the presence of three judges to scrutinize plea agreements would limit prosecutorial bargaining power. At the same time, the ability of the prior system to incorporate the perspectives of various parties to the process through overlapping discretion would return.

Finally, the panel approach would encourage intermediate sanctions that more accurately serve sentencing purposes. At sentencing, the judge's discretion to consider purposes, together with guidance from the precedential guidelines, would enhance consideration of available options. ${ }^{129}$ This result would significantly advance the goal of just, purposeful sentencing. ${ }^{130}$

126. See supra text accompanying notes 121-22.

127. More specifically, as Congress recognized, requiring a statement of reasons, 18 U.S.C. § 3553(c) (1988), makes appellate review more meaningful, provides criminal justice researchers with information on the efficacy of certain sentencing practices, and provides guidelines drafters with data. S. REP. No. 225, supra note 1 , at 80 , reprinted in 1984 U.S.C.C.A.N. at 3263.

128. The SRA permits disparity of up to $25 \%$ in factually identical cases. 28 U.S.C. $\$ 994(b)(2)$ (1988).

129. See infra notes $148-51$ and accompanying text. Commentators have emphasized the nexus between identifying purposes and choosing intermediate sanctions. See NORVAL MORRIS \& MICHAEL TONRY, BETWEEN PRISON AND PROBATION: INTERMEDIATE PUNISHMENTS IN A RATIONAL SENTENCING SYSTEM 3 (1990); Michael E. Smith, Designing and Implementing Noncustodial Penal Sanctions, 4 FED. SENTENCING REP. 27, 27 (1991) ("Lack of consensus and clarity about purpose may not matter much to those who think of the prison cell as the only penal measure available to accomplish any serious purpose. Clarity about purpose matters very much, however, when the available penal sanctions encompass everything ...."); Hoelter, supra note 40 , at $39-40$. In addition, precedential guidelines would aid the dialogue on purpose and punishment for recurrent crimes. See Lawrence S. Lustberg, The Importance of Purposes in Choosing Between Prison and Probation, 3 FED. SENTENCING ReP. 334, 335 (1991).

130. Consider an example from pre- and post-Guidelines sentencing: Defendant $A$, a contractor, pleaded guilty to bribing a government official in 1986 (pre-Guidelines) and was sentenced in 1989 to two years 


\section{Potential Criticisms}

There are, to be sure, practical concerns with the panel approach. One fear is that geographically based disparity will eliminate any possibility of nationwide sentencing uniformity. Arguably, however, local conditions should affect sentences in some instances to fulfill relevant sentencing purposes. ${ }^{131}$ For example, deterrence of alien smuggling may require the imposition of heavy prison terms in Texas, but the same sentence may have little deterrent effect and may make little sense in Massachusetts. ${ }^{132}$ In addition, the imposition of community standards, as reflected by a district court's sentences, might well result in a justifiable disparity nationwide. ${ }^{133}$ Until society reaches a consensus on sentencing purposes, it cannot be said whether certain types of disparities, such as those between districts, should be deemed "unwarranted."

A second and more formidable consideration involves resources; the last thing the overburdened federal court system needs is a sentencing process that requires three times the amount of judicial time. ${ }^{134}$ Considering, however, that judges spent only about one hour per case on sentencing prior to the Guidelines ${ }^{135}$ and that they typically terminate only about forty criminal cases a year, ${ }^{136}$ to require an average of three hours per case, or 120 hours per year, does not seem unreasonable. ${ }^{137}$ Even conceding the resource burden, the

of full-time community service and three more years of part-time service. $A$ was sentenced, at $A$ 's suggestion, to build a summer camp for children with spina bifida, finance up to $\$ 250,000$ of the project costs, and be subject to supervision by the local Spina Bifida Association. Defendant $B$, a union official, was sentenced for participation in a bribery scheme that occurred after the Guidelines had gone into effect. $B$ also proposed a structured community service program, but because of the judge's limited options under the Guidelines, $B$ was sentenced to prison for 24 months. See Hoelter, supra note 40, at 39.

131. See Denver Hearing, supra note 25, at 101 (testimony of Judge John Kane, D. Colo.) (lack of law enforcement manpower in rural areas requires especially lengthy sentences for deterrence); $i d$. at 169-70 (testimony of Donna Chavez, Assistant Attorney General, Navajo Nation) (nature of Native-American communities should affect sentencing).

132. N.Y. Hearing, supra note 54, at 49-50 (testimony of Judge Mark Wolf, D. Mass.). The Guidelines have not prevented disparate sentencing practices in different districts and circuits. See John F. Jackson, Departure From the Guidelines: The Frolic and Detour of the Circuits-How the Circuit Courts are Undermining the Purposes of the Federal Sentencing Guidelines, 94 DICK. L. REV. 605 (1990) (reporting wide disagreement among circuits regarding proper standard of review of departures); Oberlies, supra note 97, at 155-56 (reviewing Guidelines compliance rates and finding, for instance, that downward departures ranged from $0 \%$ of the sample cases in Mississippi to $29.0 \%$ in Arizona and that upward departures ranged from $0 \%$ in Massachusetts to $15.4 \%$ in the Eastern District of Texas).

133. If juries are employed, in part, to express a community's view of culpability, it is reasonable that their perspectives should also influence, to some degree, defendants' sentences.

134. See LESLIE T. WILKINS ET AL., SENTENCING GUIDELINES: STRUCTURING JUDICIAL DISCRETION 2-3 (1978).

135. See Letter from William Eldridge, Director of Research, Federal Judicial Center, to Professor Sara S. Beale, Duke University School of Law (Aug. 21, 1989), reprinted in Beale, supra note 19, app. A (preliminary data from time study indicate judges spent approximately one hour per case on sentencing).

136. In the Second Circuit, 34 criminal cases per district court judgeship were terminated in 1991. U.S. COURTS FOR THE SECOND CIRCUIT, 1991 ANNUAL REPORT 13 [hereinafter SECOND CIRCUTT REPORT].

137. This figure might be higher due to the statement of reasons requirement. However, regulations on the appropriate specificity of these opinions and even the use of standardized forms would minimize the burden. See, e.g., O'DONNELL ET AL., supra note 33, at 59 (options for implementing statement of reasons). 
added investment seems justified by the import of the sentencing decision on the individual defendant and upon society. As Judge Marvin Frankel wrote, "[E]very trial judge spends countless hours on minutiae that cannot compare in significance with the effort to formulate wise and reasoned sentences." 138 Indeed, it seems incongruous that society readily sacrifices enormous resources in determining the guilt of a defendant and yet is reluctant to invest the energy to establish the appropriate penalty. ${ }^{139}$ The impetus behind the Commission and the Guidelines was not to save money, but to further just sentencing. ${ }^{140}$ Similarly, the evaluation of the panel approach offered here should rest on the proposal's potential to improve sentencing rather than merely on its efficiency. ${ }^{141}$

Finally, the cost of panels may be less troublesome in light of the aggregate resource effect the Guidelines have had on the criminal justice system. First, judges have found sentencing under the Guidelines to be more time consuming than sentencing under the previous regime. ${ }^{142}$ While the panel approach will no doubt require even more time from judges, the point here is simply that the Guidelines do not escape this criticism either.

Second, the Guidelines represent an important component in the "severity revolution" of harsher penalties and longer terms of imprisonment, the direct result of which is a larger prison population. ${ }^{143}$ The United States already incarcerates a higher proportion of its residents than any other industrialized

138. FRANKEL, supra note 13 , at 71 .

139. The district courts of the Second Circuit completed 689 criminal trials in 1991, or 11 trials per judgeship, consuming the time of judges, clerks, secretaries, stenographers, bailiffs, probation officers, prosecutors, defense attorneys, and witnesses. SECOND CIRCUIT REPORT, supra note 136, at 13. Given the massive expenditure for determining culpability, the requirement of a few hours of a judge's time for crafting an appropriate sentence hardly seems oppressive.

140. See Alschuler, supra note 111, at 906 . The Commission's budget for 1991 is $\$ 9.6$ million. Id.

141. Again, Judge Frankel explained: "If there are not judge-hours enough to improve this vital enterprise, we should cut out other things, add judges, work harder, or do some of each." FRANKEL, supra note 13, at 71. Certainly, the impact on judges would be lessened if the process of nominating and confirming judges, which has been notoriously slow, see William Glaberson, Delays in Filling Vacancies Create U.S. Court Backlogs, N.Y. TMES, Sept. 15, 1989, at B3, were accelerated. But see Jon O. Newman, Restructuring Federal Jurisdiction: Proposals to Preserve the Federal Judicial System, 56 U. CHI. L. REV. 761, 763-64 (1989) (quality of federal judges will suffer if appointments accelerated or increased).

142. The Guidelines have increased judicial time spent on sentencing by approximately $25 \%$. FCSC REPORT, supra note 4, at 137. Unfortunately, this increased time does not improve the defendant's understanding of the reasoning underlying his sentence, but instead is used to work through the Guidelines maze. As one judge commented:

Nothing is more disconcerting to me as a District Judge than to watch a defendant and his family and others sitting in a courtroom, literally bewildered by 30 to 60 minutes of conversations about matrices, computations, adding, deducting, excluding, including, departing, not departing. This is not justice and the federal district judges in this country know that and no amount of pseudoscience, no amount of technology introduced into this process, is going to alter this fact.

Proceedings of the Fifty-First Judicial Conference of the District of Columbia Circuit, 134 F.R.D. 321, 475 (1990) (remarks of Judge José A. Cabranes, D. Conn.). In addition, the courts of appeals have faced massive numbers of sentencing appeals. See Heaney, supra note 19, at 163 (defendants raised Guidelines issues in $74 \%$ of all criminal appeals in 1989 and 1990).

143. See Alschuler, supra note 111, at 929-32, 937-38; Karle \& Sager, supra note 108, at 416-19; William W Schwarzer, Judicial Discretion in Sentencing, 3 FED. SENTENCING REP. 339, 341 (1991). 
nation. ${ }^{144}$ If trends continue, the number of federal prisoners will exceed capacity by $70 \%$ in four years, despite massive construction of new facilities. ${ }^{145}$ In enacting sentencing reform legislation, Congress clearly wished to avoid the immense costs of a burgeoning corrections population. ${ }^{146}$ There can be little doubt that abandonment of the Guidelines, with its lengthy terms of incarceration, would alleviate this burden to some extent. ${ }^{147}$

Furthermore, judges freed of the Guidelines under this new regime would not only rely less on imprisonment but make more effective use of intermediate sanctions. ${ }^{148}$ The Guidelines' focus on incarceration has limited the use of intermediate sanctions by restricting nonprison options to $10 \%$ of the sentencing grid boxes. ${ }^{149}$ Conversely, under the pre-Guidelines system, judges had the discretion to individualize sentences and made particularly frequent use of the probation alternative. ${ }^{150}$ In addition, one of the recognized attributes of the sentencing council arrangement was the enhanced debate and awareness among judges of sentencing options. ${ }^{151}$ Thus, sentencing panels should similarly promote greater application of intermediate sanctions, which will undoubtedly alleviate some of the burden on the penal system.

Taken together, these three factors indicate that the panel approach to sentencing may in fact consume fewer of the aggregate criminal justice system resources than the current Guidelines approach does.

\section{B. Appellate Review For the Development of a Common Law of Sentencing}

The British have long recognized the ability of appellate courts to harmonize the views of judges and to reduce disparity. ${ }^{152}$ Of course, thanks to the

144. The United States, with 426 prisoners for every 100,000 residents, leads all industrialized states, including South Africa (333), U.S.S.R. (268), and France (81). MARC MAUER, THE SENTENCING PROJECT, AMERICANS BEHIND BARS: A COMPARISON OF INTERNATIONAL RATES OF INCARCERATION 3, 5 (1991).

145. Karle \& Sager, supra note 108 , at 419.

146. Congress, in enacting the SRA, expressed overt concern with prison overcrowding, directing the Commission to draft Guidelines that "minimize the likelihood that the Federal prison population will exceed the capacity of the Federal prisons." 28 U.S.C. $\$ 994(\mathrm{~g})(1988)$. Studies estimate the cost of incarceration in America to be $\$ 16$ billion per year. MAUER, supra note 144, at 3.

147. However, factors other than the Guidelines, including mandatory minimum sentences, improved law enforcement techniques, and more agressive law enforcement, are also largely responsible for the rise in incarceration. See Alschuler, supra note 111, at 932.

148. Congress intended the Guidelines to embrace a variety of penalties. S. REP. No. 225 , supra note 1, at 39, reprinted in 1984 U.S.C.C.A.N. at 3222 (Guidelines "should assure the availability of a full range of sentencing options from which to select the most appropriate sentence in a particular case.").

149. Hoelter, supra note 40, at 40; see also Amendment Hearings, supra note 109, at 276. Of course, judges can and do exercise the departure power to impose probation rather than imprisonment. See, e.g., United States v. Perez, 756 F. Supp. 698, 699 (E.D.N.Y. 1991); United States v. Concepcion, 721 F. Supp. 493, 498 (S.D.N.Y. 1989). Impressive efforts are underway at the Commission to amend the Guidelines to permit nonprison sanctions. See Helen G. Corrothers, The Federal Offender: A Program of Intermediate Punishments, 4 FED. SENTENCING REP. 23 (1991).

150. See Lustberg, supra note 129 . In 1989 , only $13.5 \%$ of defendants sentenced under the Guidelines received probation-only sentences, compared to $40.0 \%$ pre-Guidelines. See Heaney, supra, note 19, at 183 .

151. See PHILLIPS, supra note 123 , at 33; Zavatt, supra note 121 , at $479-80$.

152. See D.A. ThOMAS, PRINCIPLES OF SENTENCING 4 (2d ed. 1979). 
SRA, appellate review of sentencing is also a proven method in the United States. ${ }^{153}$ Since enacting the SRA, Congress has continually shown its willingness and ability to refine and to improve appellate review procedures. ${ }^{154}$ Courts of appeals have cooperated by producing a rapidly growing body of case law. ${ }^{155}$ Unfortunately, appellate decisions, for the most part, have been hypertechnical because the restrictive Guidelines structure makes resort to first principles difficult. ${ }^{156}$

The sentencing process espoused in this Note would retain appellate review but would likely foster a more coherent common law of sentencing. First, an appellate court would still have the ability to measure the disparity of sentences against the backdrop of precedential guidelines. ${ }^{157}$ Second, the appellate court would enjoy the advantage of reviewing the reasoning of a three-judge panel.

This review mechanism would eliminate lingering, unwarranted disparities by permitting either the government or the defendant to appeal any sentence. By considering the benchmark precedential guidelines, the sentencing panel's articulated rationale, and any dissenting opinion, appellate courts would review sentences and remand for resentencing where the panel had abused its discretion. This standard is harsh enough to discourage frivolous appeals that might excessively burden the courts, yet flexible enough to permit consideration of exceptional cases inappropriately sentenced under the precedential guidelines. The standard also reflects a proper degree of deference to the trial bench's opportunities to observe the defendant and its accumulated experience.

In this way, appellate review represents the final component of a communicative process that would serve to involve all members of the judiciary in the effort to promote just and effective sentencing. By placing the responsibility for conscientious sentencing back in the hands of judges, although more diffusely and with more helpful guidance, the system would necessarily alter the spirit of the sentencing process. ${ }^{158}$ Rather than confronting the negative

153. See 18 U.S.C. § 3742 (1988).

154. See Criminal Law and Procedural Amendments Act of 1986, Pub. L. No. 99-646, § 73, 100 Stat. 3592, 3617-18; Sentencing Act of 1987, Pub. L. No. 100-182, $\$ 4-6,101$ Stat. 1266, 1266-67; Anti-Drug Abuse Act of 1988, Pub. L. No. 100-690, $\S 7103$, 102 Stat. 4181, 4416-18. All three of these Acts are codified at 18 U.S.C. $\S 3742$ (1988).

155. An effective complement is the Federal Sentencing Reporter, whose purpose is to provide information on the development of sentencing case law. Editors' Notes, 1 FED. SENTENCING REP. 2 (1988).

156. Interview with Professor Leonard Orland, University of Connecticut School of Law, in New Haven, Conn. (Nov. 17, 1991); see also United States v. Marshall, 908 F.2d 1312 (7th Cir. 1990), aff'd, 111 S. Ct. 1919 (1991).

157. Appellate review cannot minimize disparity without standards that refer to sentencing purposes. See Peter A. Ozanne, Judicial Review: A Case for Sentencing Guidelines and Just Deserts, in SENTENCING REFORM: EXPERMENTS IN REDUCING DISPARTYY 180-85 (Martin L. Forst ed., 1982); Note, Appellate Review of Primary Sentencing Decisions: A Connecticut Case Study, 69 YALE L.J. 1453, 1475 (1960).

158. The current "spiritlessness" of sentencing, see supra text accompanying notes 104-07, derives in part from attitudes underlying the sentencing reform movement, which, as one judge explained, "reflect the fears of discretionary authority, the confidence in rulemaking by administrative agencies drawing upon experts and technology, and the aspiration for a rational-if not perfect-order in social affairs so characteristic of the modern age." United States v. DiBiase, 687 F. Supp. 38, 40 (D. Conn. 1988). 
impulse to attempt to work around a set of constrictive Guidelines, judges would fulfill a constructive function as the implementers and reviewers of a new sentencing approach. Finally, the primary mode of evolution, common law development, is a proven method, familiar to both judges and the public.

\section{CONCLUSION}

Those who concluded that the pre-Guidelines system was a failure traced the fault to judges exercising discretion inconsistently and unfairly. This Note argues that restraining judicial discretion with a Guidelines matrix was both an ineffective and ill-advised response. Not only did the sentencing process lose the potential benefits of discretion, but the process became skewed in a way that promoted new, and arguably more troubling, forms of disparity. Sentencing reform that aspires to eradicate unwarranted disparity must begin by aiming to optimize the ability of discretion to account for individual differences among offenders. It should tap the abilities and experiences that judges bring to the sentencing process in a manner that elicits dialogue yet checks abuse. Only in this way can sentencing theory evolve. 